\title{
Non-Compliance With Study Schedule
}

National Cancer Institute

\section{Source}

National Cancer Institute. Non-Compliance With Study Schedule. NCI Thesaurus. Code C161411.

An indication that a study subject has not followed the schedule of activities. 